\title{
Dehydrated tomato pulp in rabbit feed: effects of incorporation rate on growth performance, carcass yield, meat quality and economic efficiency
}

\author{
A. Mennani ${ }^{1}$, Y. Arbouche ${ }^{1}$, R. Arbouche ${ }^{2}$, F. Arbouche ${ }^{2,3}$ and L. Ouzzir ${ }^{1}$ \\ 1 University of Setif, Faculty of Science of Nature and Life, Department of Agronomy, 19000, Setif, Algeria \\ ${ }^{2}$ University of Ghardaïa, Faculty of Science of Nature and Life, Department of Agronomy, 47000, Ghardaïa, Algeria
}

KEY WORDS: agro-industrial by-product, finishing, performance traits, rabbits, tomato pulp

Received: $\quad 31$ May 2021

Revised: $\quad 21$ July 2021

Accepted: 7 September 2021

${ }^{3}$ Corresponding author:

e-mail: arbouchefodil@yahoo.fr

\begin{abstract}
The economic value of animal production depends on the price of raw materials used in feed formulas and the level of incorporation of agroindustrial by-products of low-added value. The study aimed to determine the effects of incorporating dehydrated tomato pulp (DTP) at rates of 30, 40 and $60 \%$ instead of dehydrated alfalfa in the diet of fattening rabbits on growth and slaughter performances, meat quality and economic efficiency. One hundred and twenty local rabbits, called the 'white population,' weaned at 33 day of age, were randomly divided into 4 groups of 30 animals, identified and distributed in cages, 6 rabbits/cage, i.e. 5 replicates per group. There were no statistically significant differences among groups concerning growth performance for the whole study period (days 33-77). The liver weight of the $60 \%$ DTP group was positively influenced (on average $+20 \mathrm{~g}$ ) in comparison to the control, while the perirenal fat weight took values inversely proportional to the DTP incorporation rate for the experimental groups. The middle part (loin) was heavier in 30\% DTP group (on average $+68 \mathrm{~g}$ ) in comparison to the control group. The partial substitution of dehydrated alfalfa by DTP improved the economic efficiency of the $60 \%$ DTP group (on average $+0.38 \%$ ). So, DTP might remain an alternative to the substitution of alfalfa at rates of $60 \%$ without negative effects on the growth performance, slaughter performance, carcasses characteristics and at the same time it may assure cost-effectiveness.
\end{abstract}

\section{Introduction}

In rabbit farming, as for other monogastric livestock, feed represents a significant share of financial expenses, estimated at nearly $70 \%$ according to several authors (Guermah et al., 2016). In Algeria, raw materials that are added to rabbit feed formulas are mostly imported and dependent on fluctuations in foreign stock markets and the parity of the Algerian dinar (DZD), leading to a high cost of meat products.
As such, in rabbit farming, the share of ballast is generally brought by dehydrated alfalfa, very little and poorly produced in the national territory, mostly imported.

To minimize food dependence, the use of local agro-industrial by-products in domestic animal feed remains a possibility that has been studied by several authors, based on numerous experiments conducted on various species (Mennani et al., 2017, 2019; Ouzzir et al., 2020).

Dehydrated tomato pulp (DTP), a by-product of industrial tomato processing, remains a non- 
negligible prospect for substitution of dehydrated alfalfa in rabbits for fattening and has been introduced at rates below 30\% (Elazab et al., 2011; Peiretti et al., 2012; Sayed and Abdel-Azeem, 2012). In the latter study, contradictory results were presented, which allowed us to develop the subject of our research - much higher incorporation rates of DTP into rabbit feed.

Annually tomato-cultivated areas in the Algerian national territory comprise about 21434 ha on average with an average annual production of 1235400 t/year (MADR, 2016). The industrial tomato processing industry generates about $19 \%$ of the whole by-products (Valerie and Tran, 2016), bringing $234726 \mathrm{t} /$ year. All these by-products are almost entirely disposed of in public landfills. These by-products consist of husks, seeds, stalks and leaves. Their chemical compositions vary depending on the technological process used; they are rich in protein $(19.9 \%$ of dry matter (DM)), fat $(16.1 \%$ of DM), neutral detergent fibre (NDF; $55.6 \%$ of DM), acid detergent fibre (ADF; $20.3 \%$ of DM) and acid detergent lignin (ADL; $25.2 \%$ of DM) (Arbouche et al., 2018), which is important for the digestive health of rabbits (Gidenne et al., 2015). Moreover, dehydrated tomato by-products contain more essential amino acids than dehydrated alfalfa (Elazab et al., 2011).

Our study is part of a research project aimed to incorporate agro-industrial by-products in rabbit feed for fattening, as well as apricot kernel cake and date waste (Mennani et al., 2017, 2019; Ouazzir et al., 2020). Dehydrated tomato pulp in our study was a substitute for dehydrated alfalfa in the amounts of 30, 40 and $60 \%$, which will allow us to assess how the tested replacement percentages affect the growth performance of rabbits, their slaughter characteristics and the composition of meat.

\section{Material and methods}

The present study was conducted after obtaining the approval no. 08/UG/19 of the Institutional Animal Ethics Committee, Laboratory of Agriculture Department, University of Ghardaia, Algeria.

\section{Animals, diets and experimental protocol}

The study was conducted in 2020, at a professional breeding centre, located in the Wilaya of Sétif. One hundred and twenty rabbits of the local 'white population', weaned at 33 day of age, were randomly divided into 4 groups of 30 animals each. The rabbits, of equal sex ratio $(1: 1)$, with an average weight of $770.6 \mathrm{~g}$ in each group, were identified and distributed in cages, 6 rabbits/cage, i.e. 5 replicates per group.

The tomato pulps were supplied by a cannery located in the industrial zone of the Wilaya of Sétif. They were sun-dried for three days. Analyses of $\mathrm{DM}$, crude protein $(\mathrm{CP})$, crude fibre $(\mathrm{CF})$, parietal compounds (NDF, ADF and ADL), ether extract (EE), crude ash (CA) were made according to AOAC International (2005). Gross energy was determined by adiabatic calorimetry and amino acids by high-performance liquid chromatography (HPLC) (Table 1) (Arbouche et al., 2018).

Table 1. Chemical composition of dehydrated tomato pulp (DTP)

\begin{tabular}{lc}
\hline Indices & Amount \\
\hline Dry matter (DM), \% & 89.8 \\
Crude protein, \% DM & 19.9 \\
Crude fibre, \% DM & 35.3 \\
Ether extract, \% DM & 16.1 \\
Crude ash, \% DM & 4.88 \\
Nitrogen-free extract, \% DM & 13.6 \\
NDF, \% DM & 55.6 \\
ADF, \% DM & 20.3 \\
ADL, \% DM & 25.2 \\
Hemicellulose, \% DM & 35.3 \\
Gross energy, kcal/kg DM & 4063 \\
Digestible energy rabbit* kcal/kg DM & 2298 \\
Rabbit digestible protein*, g/kg DM & 130 \\
Lysine, g/100 g feed & 1.0 \\
Methionine, g/100 g feed & 0.36 \\
Cysteine, g/100 g feed & 0.31 \\
\hline
\end{tabular}

NDF - neutral detergent fibre, ADF - acid detergent fibre, ADL - acid detergent lignin; * - estimated by the equation of Lebas (2016)

Four compound feeds were formulated using WUFFDA (Food Formulation Software for Feeding Rabbits, 2002, ver. 1.4): one control feed ( $0 \%$ of dehydrated alfalfa substituted with DTP) and three experimental feeds, in which 30,40 and $60 \%$ of dehydrated alfalfa were substituted with DTP (Table 2). Animals were weighed individually at 33, 44, 58 and 77 day of age. The feed was distributed ad libitum and consumption was monitored for each cage with weighing of the refusals. 
Table 2. The formula of feeds distributed according to the substitution rate of alfalfa by dehydrated tomato pulp (DTP)

\begin{tabular}{|c|c|c|c|c|}
\hline \multirow[t]{2}{*}{ Indices } & \multicolumn{4}{|c|}{$\begin{array}{l}\text { DTP incorporation, } \% \text { of } \\
\text { dehydrated alfalfa substitution }\end{array}$} \\
\hline & 0 & 30 & 40 & 60 \\
\hline \multicolumn{5}{|l|}{ Ingredients, $\mathrm{kg} / 100 \mathrm{~kg}$ of feed } \\
\hline maize & 20 & 20 & 20 & 20 \\
\hline soyabean meal & 12.7 & 12.7 & 12.7 & 12.7 \\
\hline wheat bran & 32 & 32 & 32 & 32 \\
\hline wheat straw & 4.7 & 4.7 & 4.7 & 4.7 \\
\hline dehydrated alfalfa & 29 & 20.3 & 17.4 & 11.6 \\
\hline DTP & 0 & 8.7 & 11.6 & 17.4 \\
\hline salt ( $\mathrm{NaCl})$ & 0.5 & 0.5 & 0.5 & 0.5 \\
\hline MVS & 0.5 & 0.5 & 0.5 & 0.5 \\
\hline calcium carbonate & 0.5 & 0.5 & 0.5 & 0.5 \\
\hline L-lysine & 0.08 & 0.04 & 0.05 & 0.03 \\
\hline DL-methionine & 0.02 & 0.06 & 0.05 & 0.07 \\
\hline \multicolumn{5}{|l|}{ Calculated nutrient levels } \\
\hline crude fibre, $\%$ & 15.1 & 15.5 & 15.8 & 16.4 \\
\hline NDF, $\%$ & 36.6 & 37.1 & 37.2 & 37.5 \\
\hline$A D F, \%$ & 20.1 & 20.5 & 20.6 & 20.9 \\
\hline$A D L, \%$ & 4.3 & 5.4 & 5.8 & 6.5 \\
\hline hemicellulose, $\%$ & 16.6 & 16.6 & 16.6 & 16.6 \\
\hline lysine, $\%$ & 0.83 & 0.84 & 0.86 & 0.88 \\
\hline methionine, $\%$ & 0.29 & 0.27 & 0.26 & 0.27 \\
\hline total sulphur amines, $\%$ & 0.50 & 0.52 & 0.53 & 0.55 \\
\hline $\mathrm{DP}^{*}, \%$ & 10.6 & 10.7 & 10.8 & 10.9 \\
\hline $\mathrm{DE}^{*}, \mathrm{kcal} / \mathrm{kg}$ & 2335 & 2374 & 2387 & 2412 \\
\hline metabolizable energy, kcal/kg & 2187 & 2213 & 2222 & 2239 \\
\hline cellulose vs ADF-ADL, $\%$ & 15.7 & 15.1 & 14.8 & 14.4 \\
\hline calculated DP/DE, g/1000 kcal & 48.4 & 48.6 & 48.6 & 48.7 \\
\hline
\end{tabular}

MVS - mineral and vitamin supplement composed of: $\mathrm{mg} / \mathrm{kg}$ : calcium 150.7, sodium chloride 332000 , vitamin E 1500 , vitamin K 200, vitamin $B_{1} 100$, vitamin $B_{2} 450$, vitamin $B_{3} 780$, vitamin $B_{6} 150$, vitamin $B_{12} 1$, PP 1000 , folic acid 50 , biotin 1.5 , choline chloride 35000 , iron 3600 , copper 2250 , zinc 7500 ; IU/kg: vitamin A 800000 , vitamin $D_{3}$ 150 000; NDF - neutral detergent fibre, ADF - acid detergent fibre, $A D L$ - acid detergent lignin, DP - digestible protein, DE - digestible energy; * - estimated by the equation of Lebas (2016)

\section{Growth performances}

Average daily gain (ADG; g/day), daily feed intake (DFI; g/day) and feed conversion ratio (FCR; $\mathrm{g}$ feed/g weight) were calculated for selected periods (days 33-44, 44-58 and 58-77) and the whole 44-day experimental trial (days 33-77). Water was available ad libitum through automatic pipette-type drinkers.

\section{Slaughtering and carcass parameters, and meat quality}

Slaughter parameters, carcass characteristics and meat quality were determined on 10 animals, taken randomly from each group, at day 77 of age, according to the methods proposed by Dalle Zotte et al. (2009).
Slaughtering and carcass parameters were: live weight at slaughter (LWS; g); hot carcass weight (HCW; g); cold carcass weight after $24 \mathrm{~h}$ in cold storage (CCW; g); hot carcass yield $(\mathrm{HCY}=\mathrm{HCW} /$ LWS $\times 100 ; \%)$ and cold carcass yield $(\mathrm{CCY}=$ $\mathrm{CCW} / \mathrm{LWS} \times 100 ; \%)$; liver weight (LW; g); liver weight to live weight ratio (LW / LWS $\times 100 ; \%$ ); perirenal fat weight (PFW; g); perirenal fat weight to live weight ratio $(\mathrm{PFW} / \mathrm{LWS} \times 100 ; \%)$; perirenal fat weight to hot carcass weight ratio ( $\mathrm{PFW} / \mathrm{HCW} \times$ 100; \%); skin weight (SW; g); skin weight to live weight ratio (SW / LWS $\times 100 ; \%)$; full digestive tract weight (FDTW; g); full digestive tract weight to live weight ratio (FDTW / LWS $\times 100$; $\%$ ); foreend weight (FEW; g); hind-end weight (HEW; g); intermediate saddle weight (ISW; g); fore-end weight to hot carcass weight ratio (FEW / $\mathrm{HCW} \times 100, \%$ ), hind-end weight to hot carcass weight ratio (HEW / $\mathrm{HCW} \times 100, \%)$ and intermediate saddle weight to hot carcass weight ratio (ISW / $\mathrm{HCW} \times 100, \%$ ).

After slaughter and dissection of meat, the chemical composition of meat was determined. The samples of each animal were homogenized in a blender and then lyophilized to assess moisture, protein content, ether extract and ash (AOAC International, 2005) with three replicates. The $\mathrm{pH}_{24 \mathrm{~h}}$ was measured at $24 \mathrm{~h}$ post-mortem by inserting the electrode of a pH meter (HI 8424 Microcomputer; Hanna Instruments, Woonsocket, RI, USA) directly into the pectoral muscle (longissimus lumborum) ( $2 \mathrm{~cm}$ deep).

\section{Statistical analysis}

The data were prepared using Microsoft Excel (Microsoft, Redmont, WA, USA). Statistical analysis and comparison of the means between different diets (control and three experimental ones) were performed by unidirectional analysis of variance using the SPSS software version 21 (IBM Corp., Armonk, NY, USA). Student-Newman-Keuls and Duncan's tests were done if a significant difference at $5 \%$ standard error was found $(P<0.05)$.

\section{Economic efficiency}

Economic efficiency was calculated from the equation by Asar et al. (2010):

economic efficiency $(\%)=($ net income $/$ total feed

where:

$$
\text { cost }) \times 100 \text {; }
$$

net income $=$ income from total weight gain - total feed cost;

income from total weight gain = average weight gain $(\mathrm{kg} / \mathrm{subject}) \times$ price of $1 \mathrm{~kg}$ of LWS;

total feed cost $=$ average feed intake $(\mathrm{kg} /$ subject $) \times$ price of $1 \mathrm{~kg}$ of feed. 
The cost of each $\mathrm{kg}$ of feed for the control and experimental diets was calculated based on the price of ingredients on the local market at the time of the experiment (the year 2020). Ancillary costs were not considered.

For the experimental batch, the total feed cost also included the cost of purchasing DTP (Table 3). All prices are presented in Algerian dinar (DZD; $1 \mathrm{DZD}=0.0062 \mathrm{EUR})$

Table 3. Data used for dehydrated tomato pulp (DTP) cost estimation

\begin{tabular}{lc}
\hline Indices & Cost, DZD/t \\
\hline Parameters value & \\
$\quad$ purchase & 5 \\
transport cost & 100 \\
truck unloading & 35 \\
treatment & \\
$\quad$ energy cost (drying) & 10 \\
$\quad$ time required for drying & $2 \mathrm{t} / \mathrm{h}$ \\
$\quad$ total labour cost & 10 \\
$\quad$ cost of depreciation of equipment & 100 \\
Total & 250 \\
\hline
\end{tabular}

DZD - Algerian dinar

The cost of production of DTP was calculated according to the direct cost method, which consists of allocating the direct fixed expenses specific to the production of DTP. The common expenses were not negligible but they were reported on the whole of the products of the company because they are difficult to evaluate in our case which relates to only one by-product.

The basic salary in Algeria (SMIG) is $18000 \mathrm{DZD} /$ month. If we accept $35000 \mathrm{DZD}$ (gross salary + employer's contributions) as the average salary per month, the salary for $1 \mathrm{~h}$ would be about 200 DZD.

The cost of energy was calculated by estimating the energy consumption of the equipment used for the production of DTP, knowing in the framework of professionals, each $\mathrm{kWh}$ is charged at $4.472 \mathrm{DZD} / \mathrm{kWh}$ (Sonelgaz, 2019).

The depreciation of the equipment was estimated according to the purchase prices of the equipment (e.g., dryer) that exists on the market and according to the average capacity of the companies carrying out the drying of the tomato pulps.

\section{Results}

\section{Growth performances}

Only the weight at 44 day of age was positively influenced $(P<0.05)$ by the different substitution rates of dehydrated alfalfa with DTP (Table 4),
Table 4. Changes in daily feed intake (DFI (g/day)), weight growth (g), average daily gain (ADG (g/day) and feed conversion ratio (FCR ( $\mathrm{g}$ feed/g weight)) during fattening of rabbits according to the percentage of dehydrated tomato pulp (DTP) incorporation

\begin{tabular}{|c|c|c|c|c|c|c|}
\hline \multirow[t]{2}{*}{ Indices } & \multicolumn{4}{|c|}{$\begin{array}{l}\text { DTP incorporation, } \% \text { of dehydrated } \\
\text { alfalfa substitution }\end{array}$} & \multirow[t]{2}{*}{ SEM } & \multirow[t]{2}{*}{$P$-value } \\
\hline & 0 & 30 & 40 & 60 & & \\
\hline $\mathrm{DFI}_{33-44 \mathrm{~d}}$ & $88.0^{\mathrm{a}}$ & $86.3^{b}$ & $86.0^{b}$ & $86.7^{\mathrm{b}}$ & 0.058 & 0.01 \\
\hline $\mathrm{DFI}_{44-58 \mathrm{~d}}$ & $96.1^{\mathrm{b}}$ & $97.8^{\mathrm{a}}$ & $99.2^{\mathrm{a}}$ & $98.3^{\mathrm{a}}$ & 0.077 & 0.02 \\
\hline $\mathrm{DFI}_{58-77 \mathrm{~d}}$ & 116 & 115 & 117 & 118 & 0.185 & 0.09 \\
\hline $\mathrm{DFI}_{33-77 \mathrm{~d}}$ & 99.7 & 99.7 & 101 & 101 & 0.067 & 0.08 \\
\hline \multicolumn{7}{|c|}{ Weight, at day } \\
\hline 33 & 770 & 777 & 764 & 764 & 10.2 & 0.46 \\
\hline 44 & $1117^{b}$ & $1177^{a}$ & $1189^{a}$ & $1187^{a}$ & 12.8 & 0.02 \\
\hline 58 & 1510 & 1499 & 1529 & 1508 & 15.1 & 0.889 \\
\hline 77 & 2006 & 2002 & 2012 & 2011 & 18.0 & 0.13 \\
\hline$D G_{33-44 d}$ & $31.5^{\mathrm{b}}$ & $36.4^{a}$ & $38.6^{a}$ & $38.4^{a}$ & 0.372 & 0.001 \\
\hline $\mathrm{ADG}_{44-58 \mathrm{~d}}$ & $28.1^{\mathrm{a}}$ & $23^{b}$ & $24.3^{b}$ & $22.9^{b}$ & 0.353 & 0.02 \\
\hline$A D G_{58-77 d}$ & 26.1 & 26.5 & 25.4 & 26.5 & 0.330 & 0.665 \\
\hline$A D G_{33-77 d}$ & 28.1 & 27.8 & 28.4 & 28.3 & 0.294 & 0.532 \\
\hline $\mathrm{FCR}_{33-44 \mathrm{~d}}$ & $2.8^{a}$ & $2.3^{b}$ & $2.3^{b}$ & $2.2^{b}$ & 0.049 & 0.01 \\
\hline $\mathrm{FCR}_{44-58 \mathrm{~d}}$ & $3.4^{\mathrm{b}}$ & $4.3^{\mathrm{a}}$ & $4.1^{\mathrm{a}}$ & $4.3^{\mathrm{a}}$ & 0.071 & 0.02 \\
\hline $\mathrm{FCR}_{58-77 \mathrm{~d}}$ & 4.4 & 4.4 & 4.6 & 4.5 & 0.710 & 0.83 \\
\hline $\mathrm{FCR}_{33-77 \mathrm{~d}}$ & 3.5 & 3.6 & 3.6 & 3.6 & 0.049 & 0.44 \\
\hline
\end{tabular}

a-b - values with different superscripts within the same row are significantly different at $P<0.05$; SEM - standard error of the mean

with a mean difference of $+67 \mathrm{~g}$. At all other time points (days 58 and 77 of age), there was no difference among groups concerning weight gain $(P>0.05)$.

The $\mathrm{ADG}_{33-44 \mathrm{~d}}$ values of all three experimental groups were similar and significantly higher on average by $+6.3 \mathrm{~g} /$ day in comparison to the control group; while the $\mathrm{ADG}_{44-58 \mathrm{~d}}$ values for experimental groups were decreased (on average $-4.7 \mathrm{~g} /$ day) in comparison to the control group. The $\mathrm{ADG}_{58-77 \mathrm{~d}}$ and $\mathrm{ADG}_{33-77 \mathrm{~d}}$ of all the groups were similar.

The FCR $_{33-44 d}$ of the control group was the highest $(P<0.05)$ in comparison to experimental groups, which recorded a similar mean value of 2.26, creating a difference with the control group of $-0.5 \mathrm{~g} / \mathrm{g}$. The experimental groups (30, 40 and $60 \%$ DTP) recorded significantly higher values in $\mathrm{FCR}_{44-58 \mathrm{~d}}$ with a difference of $+0.83 \mathrm{~g} / \mathrm{g}$ in comparison to the control group. The same changes were stated for $\mathrm{DFI}_{33-44 \mathrm{~d}}$ and $\mathrm{DFI}_{44-58 \mathrm{~d}}$ in the experimental groups with lower values in the first phase $(-1.7 \mathrm{~g} /$ day in comparison to the control group) and higher values in the second one $(+2.33 \mathrm{~g} /$ day in comparison to the control group). For all other rearing phases (days 58-77 and 33-77), the FCR and DFI values were identical among all groups. 
Table 5. Evolution of slaughter parameters, carcass characteristics, and chemical composition of meat of fattening rabbits according to the percentage of dehydrated tomato pulp (DTP) incorporation

\begin{tabular}{|c|c|c|c|c|c|c|}
\hline \multirow{2}{*}{ Indices } & \multicolumn{4}{|c|}{ DTP incorporation, \% of dehydrated alfalfa substitution } & \multirow{2}{*}{ SEM } & \multirow{2}{*}{$P$-value } \\
\hline & 0 & 30 & 40 & 60 & & \\
\hline \multicolumn{7}{|l|}{ Slaughtering parameters } \\
\hline live weight at slaughter (LWS), g & 2028 & 2051 & 2056 & 2000 & 11.8 & 0.38 \\
\hline hot carcass weight (HCW), g & 1320 & 1303 & 1260 & 1246 & 12.2 & 0.22 \\
\hline cold carcass weight (CCW), g & 1273 & 1270 & 1220 & 1215 & 12.9 & 0.43 \\
\hline HCW/LWS yield, \% & 65.1 & 63.5 & 61.2 & 62.3 & 0.594 & 0.17 \\
\hline CCW/LWS yield, \% & 62.8 & 61.9 & 59.3 & 60.7 & 0.518 & 0.15 \\
\hline \multicolumn{7}{|l|}{ Carcass characteristics } \\
\hline liver weight (LW), g & $70.0^{\mathrm{b}}$ & $81.6^{\mathrm{ab}}$ & $83.3^{\mathrm{ab}}$ & $90.0^{\mathrm{a}}$ & 6.98 & 0.04 \\
\hline LW/LWS yield, \% & $3.4^{b}$ & $4.0^{\mathrm{ab}}$ & $4.0^{\mathrm{ab}}$ & $4.5^{\mathrm{a}}$ & 0.348 & 0.046 \\
\hline perirenal fat weight (PFW), g & $31.7^{\mathrm{a}}$ & $26.7^{b}$ & $18.3^{c}$ & $13.3^{\mathrm{d}}$ & 0.726 & 0.001 \\
\hline PFW/LWS yield, \% & $1.6^{\mathrm{a}}$ & $1.3^{b}$ & $0.9^{c}$ & $0.7^{c}$ & 0.036 & 0.001 \\
\hline PFW/HCW yield, $\%$ & $2.4^{\mathrm{a}}$ & $2.0^{\mathrm{b}}$ & $1.4^{c}$ & $1.0^{\mathrm{d}}$ & 0.051 & 0.001 \\
\hline skin weight (SW), g & 273 & 273 & 271 & 270 & 2.82 & 0.83 \\
\hline SW/LWS yield, \% & 13.5 & 13.3 & 13.2 & 13.5 & 0.110 & 0.81 \\
\hline full digestive tract weight (FDTW), g & $323^{b}$ & $445^{a}$ & $462^{\mathrm{a}}$ & $455^{\mathrm{a}}$ & 5.89 & 0.01 \\
\hline FDTW/LWS yield, $\%$ & $15.9^{b}$ & $21.7^{\mathrm{a}}$ & $22.4^{a}$ & $22.7^{\mathrm{a}}$ & 0.243 & 0.01 \\
\hline fore-end weight (FEW), g & $223^{b}$ & $252^{\mathrm{a}}$ & $240^{\mathrm{ab}}$ & $248^{\mathrm{ab}}$ & 5.56 & 0.03 \\
\hline hind-end weight (HEW), g & $368^{\mathrm{ab}}$ & $398^{a}$ & $361^{b}$ & $359^{b}$ & 4.75 & 0.01 \\
\hline intermediate saddle weight (ISW), g & $327^{b}$ & $395^{\mathrm{a}}$ & $363^{\mathrm{ab}}$ & $357^{\mathrm{ab}}$ & 4.33 & 0.01 \\
\hline FEW/HCW yield, $\%$ & $16.9^{\mathrm{b}}$ & $19.3^{\mathrm{a}}$ & $19.1^{\mathrm{a}}$ & $19.9^{\mathrm{a}}$ & 0.484 & 0.03 \\
\hline HEW/HCW yield, \% & $27.9^{\mathrm{ab}}$ & $30.5^{\mathrm{a}}$ & $28.7^{\mathrm{b}}$ & $28.8^{\mathrm{b}}$ & 0.435 & 0.02 \\
\hline ISW/HCW yield, \% & $24.7^{b}$ & $30.3^{a}$ & $28.9^{\mathrm{ab}}$ & $28.6^{\mathrm{ab}}$ & 0.389 & 0.03 \\
\hline \multicolumn{7}{|l|}{ Chemical composition of the meat } \\
\hline $\mathrm{pH}_{24 \mathrm{~h}}$ & $6.0^{\mathrm{b}}$ & $7.0^{\mathrm{a}}$ & $6.9^{\mathrm{a}}$ & $6.7^{\mathrm{a}}$ & 0.035 & 0.001 \\
\hline moisture, \% DM & $61.7^{\mathrm{b}}$ & $65.9^{\mathrm{a}}$ & $65.8^{\mathrm{a}}$ & $65.8^{\mathrm{a}}$ & 0.230 & 0.001 \\
\hline protein, \% DM & $20.9^{b}$ & $23.9^{\mathrm{a}}$ & $23.0^{\mathrm{a}}$ & $23.5^{\mathrm{a}}$ & 0.137 & 0.002 \\
\hline fat, \% DM & $7.8^{b}$ & $9.6^{\mathrm{a}}$ & $8.9^{\mathrm{a}}$ & $9.8^{\mathrm{a}}$ & 0.084 & 0.003 \\
\hline ash, \% DM & 1.02 & 1.02 & 1.05 & 1.04 & 0.003 & 0.102 \\
\hline
\end{tabular}

\section{Slaughter and carcass characteristics}

The slaughter parameters of all experimental groups were not influenced by the rate of alfalfa substitution with DTP (Table 5).

The LW was positively influenced by the substitution of dehydrated alfalfa with DTP in the amount of $60 \%$, with the difference in relation to the control group by an average of $+20 \mathrm{~g}$; however, no differences were stated between the three experimental groups in the case of LW and LW/LWS ratio (Table 5). On the other hand, the PFW took values inversely proportional to the DTP incorporation rate for the experimental groups, with a statistical difference of $-5 \mathrm{~g}$ for the $60 \%$ DTP group in comparison to the $40 \%$ DTP group; of $-13.4 \mathrm{~g}$ in comparison to the $30 \%$ group and of $-18.4 \mathrm{~g}$ in comparison to the control. For the PFW/LWS and PFW/HCW ratios, a similar pattern was noted as for PFW.

The SW and its ratio to LWS (SW/LWS) were not influenced by the rate of substitution of dehydrated alfalfa with DTP (Table 5), but the FDTW was positively influenced $(P<0.05)$ with a difference of $+131 \mathrm{~g}$ (on average) concerning the control; the same annotation was made for the ratios FDTW/LWS with a difference of $+6.37 \%$ (on average) $(P<0.05)$. The FEW took an optimal value ( $+29 \mathrm{~g}$ in comparison to the control group) for the $30 \%$ DTP group; while the 40 and $60 \%$ DTP groups did not differ from either control group or $30 \%$ DTP group. For HEW, a significantly higher value was noted for the $30 \%$ DTP group in comparison to the 40 and $60 \%$ DTP groups; however, none of the experimental groups differed from the control group. The ISW recorded a significantly higher weight for the $30 \%$ DTP group in comparison to the control group $(P<0.05)(+68 \mathrm{~g}$ on average), while the 40 and $60 \%$ DTP groups did not differ from either control group or 30\% DTP group. The successive ratios of these two last parameters (HEW and ISW) to the HCW recorded values in the same direction as the evolution of their weights. 


\section{Meat quality}

The partial incorporation of DTP in substitution of dehydrated alfalfa, influenced the $\mathrm{pH}_{24 \mathrm{~h}}$ of the meat by neutralization of the acidity and impregnated similar values for the three experimental groups, bringing the difference with the control on average by +0.9 points (Table 5). There was also an improvement in moisture, protein content and fat content (on average by $+4.1,+2.57$ and $+1.63 \%$, respectively) in all three examined groups in comparison to the control group. The ash content was not influenced by the incorporation of DTP.

\section{Economic efficiency}

The partial substitution of dehydrated alfalfa by DTP in the diet of rabbits for fattening improved the economic efficiency, especially for the $60 \%$ DTP group, with a difference from the control group of $+0.38 \%$ (Table 6 ). For the same group, there was also an improvement in the price per one $\mathrm{kg}$ of feed produced $(-4.77 \mathrm{DZD})$ as well as in the total feed cost $(18 \mathrm{DZD} / \mathrm{kg})$. The net income per kilogram of meat produced tended to improve proportionally to the substitution rates of alfalfa by DTP with an optimal value of $+22.6 \mathrm{DZD} / \mathrm{kg}$ for the $60 \%$ DTP group. the same growth curve, and work carried out on rabbits of local populations and selected breeds have shown that sex does not affect live weight (Lakabi et al., 2004).

Partial incorporation of DTP did not induce a significant difference in live weights at 77 day of age for all groups of rabbits. This finding remains consistent with the results reported by Elazab et al. (2011), Peiretti et al. (2012) and Sayed and AbdelAzeem (2012), who reported that no significant difference was recorded in live weights of rabbits fattened with feed containing up to $30 \%$ of DTP. In contrast, Sayed and Abdel-Azeem (2012) found that rabbits fed with $20 \%$ DTP recorded the highest values in body weight. The $\mathrm{ADG}_{33-77 \mathrm{~d}}$ was similar among groups, such a result corroborate with those of Peiretti et al. (2012); however, remain contrary to those of Sayed and Abdel-Azeem (2012) and Peiretti et al. (2013) which indicated a higher ADG for rabbits fed a diet containing 20\% DTP. The growth rates obtained in the present study are similar to those reported by Lounaouci-Ouyed et al. (2011) (28.1 g/day) but lower than those of Kadi et al. (2017) (35 g/day), Benali et al. (2018) (34 g/day), Berchiche and Kadi (2002) (30 g/day) and Mennani et al. (2019) (32 g/day). These different authors worked on the

Table 6. Economic efficiency of partial substitution of alfalfa by dehydrated tomato pulp (DTP) in rabbits for fattening

\begin{tabular}{|c|c|c|c|c|}
\hline \multirow{2}{*}{ Parameters } & \multicolumn{4}{|c|}{ DTP incorporation, \% of dehydrated alfalfa substitution } \\
\hline & 0 & 30 & 40 & 60 \\
\hline Live weight at day $33, \mathrm{~g}$ & 770 & 777 & 764 & 764 \\
\hline Live weight at day $77, \mathrm{~g}$ & 2006 & 2002 & 2012 & 2011 \\
\hline Total weight gain, $\mathrm{kg}$ & 1.24 & 1.23 & 1.25 & 1.25 \\
\hline Selling price, DZD/kg live weight & 400 & 400 & 400 & 400 \\
\hline Income from total weight gain, DZD & 494 & 490 & 499 & 498 \\
\hline Total feed intake per rabbit, $\mathrm{kg}$ & 4.5 & 4.51 & 4.6 & 4.6 \\
\hline Price of one $\mathrm{kg}$ of feed, DZD & 37.4 & 35.0 & 34.2 & 32.6 \\
\hline Total feed cost, DZD/kg & 168 & 157 & 157 & 150 \\
\hline Economic efficiency, \% & 1.94 & 2.10 & 2.17 & 2.32 \\
\hline Net income per kg of meat produced, DZD $/ \mathrm{kg}$ & 326 & 332 & 341 & 348 \\
\hline
\end{tabular}

DZD - Algerian dinar (1 DZD = 0.0062 EUR)

\section{Discussion}

The overall mortality rate remained low $(\leq 6 \%)$, it was due to the transfer after weaning and the adaptation of the subjects to their new rearing conditions as stated by De Blas (2013) and remained within the range of the standards advanced by Kadi et al. (2012).

The sex of the rabbits did not gain particular attention because Ouhayoun et al. (1983) observed that up to 20 week of age, males and females follow same local strain, allowing us to define a range of growth between 28 and $35 \mathrm{~g}$ day and which remains linked to the nutritional balance of the recommended diets.

In the present study, the $\mathrm{DFI}_{33-77 \mathrm{~d}}$ were similar for all groups, although the content of ADL was higher in the experimental groups (4.3 vs $6.5 \%$ ), which should increase the average DFI according to Gidenne et al. (2015), who related the voluntary intake of rabbits with the concentration of ADL in the 
feed. Sawal et al. (1996) also report that incorporation of $10-20 \%$ DTP into rabbit diets increased DFI, as well as Sayed and Abdel-Azeem (2012) found that DFI of rabbits was significantly affected by the level of DTP incorporation in diets. The FCR ${ }_{33-77 \mathrm{~d}}$ was the same for all groups, which is consistent with the results put forward by Sayed and Abdel-Azeem (2012) and Peiretti et al. (2012) with diets up to 30\% DTP incorporation. However, Sawal et al. (1996) found a decrease in FCR proportional to increasing DTP incorporation in diets.

For the experimental groups, liver weight and its ratio to live weight (LW/LWS) increased significantly in line with the findings by Kavamoto et al. (1970) but remain in contradiction with those found by Peiretti et al. (2013) and Sayed and Abdel-Azeem (2012) who did not find any improvement in the carcass characteristics of the rabbits fed diet with DTP addition up to $30 \%$. Perirenal fat weight and its ratio decreased proportionally to the rate of incorporation of DTP $(30,40$ and $60 \%)$ in the rations of the experimental groups, which was not reported by Elazab et al. (2011), Peiretti et al. (2013) and Grioui et al. (2021) who found no changes in carcass characteristics of rabbits fed with DTP incorporation rates below $30 \%$. The weight of the full digestive tract of all the experimental groups recorded a similar and significantly higher value than that of the control as pointed out by Grioui et al. (2021) for incorporation rates of 10 and $20 \%$ of DTP. This would be due to a higher concentration of ADL in the experimental groups $(+1.1,+1.5$ and $+2.2 \%$ for 30,40 and $60 \%$ groups, respectively) as well as to the level of carotenoids, including lycopene, contained in the dehydrated tomato husks, which remain poorly assimilated if not cooked. However, for incorporation rates of 3 and 6\% DTP, Peiretti et al. (2013) did not find an increase in full digestive tract weight. For DTP incorporation rates of less than $30 \%$, Elazab et al. (2011) recorded no significant difference in the weights of the front, back and middle part of the rabbits; however in the present trial, with the incorporation rates of 30, 40 and $60 \%$, an improvement in the weights of these three parameters of the carcass was found.

The value of 6.9 recorded for the $\mathrm{pH}_{24 \mathrm{~h}}$ of the longissimus lumborum muscle of the experimental groups had an influence, on the one hand, on the conservation of the meat because the proteolytic microorganisms quickly develop bad odours there (Dalle Zotte, 2014) and, on the other hand on its quality through the tenderness of the cooked meat which is linked to the degradation of glyco- gen and the release of lactate after slaughter, however, a $\mathrm{pH}_{24 \mathrm{~h}}$ lower than 6 (around 5), would lead to too firm meat because the water retention capacity would be decreased (Wang et al., 2016). Substitution rates higher than $30 \%$ in DTP in the rations of fattening rabbits result in an improvement of the protein and fat content of the meat, in contrast to incorporation rates lower than $30 \%$, which did not lead to any changes in the chemical composition of the meat (Peiretti et al. (2013) and Elazab et al. (2011)).

The net income per $\mathrm{kg}$ of meat in the $60 \%$ group was significantly improved because the cost price of locally produced DTP remains low compared to dehydrated alfalfa which is mostly imported to Algier.

\section{Conclusions}

Like dehydrated alfalfa, dehydrated tomato pulp (DTP) can be considered as a source of protein and fibre for the rabbit. Substitution of $60 \%$ of dehydrated alfalfa with DTP does not interfere with growth performance, slaughter parameters and carcass characteristics. However, it reduces the external fatness of the carcass and reduces the cost price of the consumed feed. To improve the feed efficiency, it would be interesting to consider the use of this agroindustrial by-product after cooking.

\section{Conflict of interest}

The authors declare that there is no conflict of interest.

\section{References}

AOAC International, 2005. Official Methods of Analysis of AOAC International. 18 $8^{\text {th }}$ Edition. Gaithersburg, MD (USA)

Arbouche F., Arbouche R., Arbouche Y., Arbouche H.S., Mennani A., 2018. Tables of Composition and Nutritional Value of North African Raw Materials and Agro-industrial By-products for Ruminant Feed (in French). Ferhat Abbas Sétif University. Setif (Algeria), https://libroterra.com/shop/nature/tables-decomposition-et-de-valeur-nutritive-des-matieres-premiereset-sous-produits-agroindustriels-de-lafrique-du-nord-pourlalimentation-des-ruminants/

Asar M.A., Osman M., Yakout H.M., Safoat A., 2010. Utilization of corn-cob meal and faba bean straw in growing rabbit's diets and their effects on performance, digestibility, and economical efficiency. Egypt. Poult. Sci. 30, 415-442

Benali N., Ainbaziz H., Dahmani Y., Djellout B., Belabbas R., Tennah S., Zenia S., Cherrane M., Temim S., 2018. Effect of dietary energy content on performance and some biological parameters in growing rabbits (in French). Livest. Res. Rural Dev. 30(3), 51, http://www.Irrd.org//rrd30/3/na.be30051.html 
Berchiche M., Kadi S.A., 2002. The kabyle rabbits (Algeria). In: M.H. Khalil, M. Baselga (Editors). Rabbit Genetic Resources in Mediterranean Countries (Options Méditerranéennes: Série B: Etudes et Recherches; no. 38). CIHEAM. Zaragoza (Spain), pp. 15-20, http://om.ciheam.org/article. php?IDPDF=2600006

Dalle Zotte A., Princz Z., Metzger Sz., Szabó A., Radnai I., Biró-Németh E., Orova Z., Szendrö Zs., 2009. Response of fattening rabbits reared under different housing conditions. 2. Carcass and meat quality. Livest. Sci. 122, 39-47, https://doi. org/10.1016/j.livsci.2008.07.021

Dalle Zotte A., 2014. Dietary benefits: Rabbit must tame the consumer. Viandes et Produits Carnés 23, 161-167

De Blas J.C., 2013. Nutritional impact on health and performance in intensively reared rabbits. Animal 7, Suppl. 1, 102-111, https://doi.org/10.1017/S1751731112000213

Elazab M.A., Zahran S.M., Ahmed M.H., Elkomi A.E., 2011. Productive performance of growing rabbits fed diet containing different levels of tomato pomace. Benha Vet. Med. J. 22(2), 46-57

Gidenne T., Lebas F., Savietto D., Dorchies P., Duperray J., Davoust C., Lamothe L., 2015. Chapter 5: Nutrition and feeding (in French: Nutrition et alimentation). In: T. Gidenne (Editor). The Rabbit: from Biology to Farming (in French: LE LAPIN. De la biologie à l'élevage). Editions Quae. Versailles (France), pp. 139-184, https://www.quae.com/product/1342/9782759224180/therabbit

Guermah H., Maertens L., Berchiche M., 2016. Nutritive value of brewers' grain and maize silage for fattening rabbits. World Rabbit Sci. 24, 183-189, https://doi.org/10.4995/ wrs.2016.4353

Grioui N., Boukhris H., Damergi C., Hajii W., Riahi H., Abderrabba M., Najar T., Mejri M., 2021. Dried tomato pomace in rabbit nutrition: effects on carcass characteristics and meat quality. Turk. J. Vet. Anim. Sci. 45, 281-287, https://doi.org/10.3906/ vet-2004-114

Kadi S.A., Belaidi-Gater N., Oudai H., Bannelier C., Berchiche M., Gidenne T., 2012. Nutritive value of fresh sulla (Hedysarum flexuosum) as a sole feed for growing rabbits. In: Proceeding of the $10^{\text {th }}$ World Rabbit Congress. Sharm El-Sheikh (Egypt). World Rabbit Science Association (WRSA), pp. 507-511

Kadi S.A., Mouhous A., Djellal F., Senhadji Y., Tiguemit N., Gidenne T., 2017. Fig-tree leaves and Sulla hay (Hedysarum flexuosum) in the diet of growing rabbits (in French). Livest. Res. Rural Dev. 29(5), 86, http://www.Irrd.org//rrd29/5/kadi29086.html

Kavamoto E.T., Romeiro M.M., Spers A.A., 1970. By-product of the tomato industry in rations for growing and finishing rabbits. Boletim de Industria Animal 27/28, 463-473

Lakabi D., Zerrouki N., Lebas F., Berchiche M., 2004. Growth performances and slaughter traits of a local kabylian population of rabbits reared in Algeria: effects of sex and rearing season. In: Proceeding of the $8^{\text {th }}$ World Rabbit Congress. Puebla (Mexico). World Rabbit Science Association (WRSA), pp. 1396-1402

Lebas F., 2016. Estimation of digestible energy content and protein digestibility of raw materials by the rabbit, with a system of equations. In: Proceeding of the $11^{\text {th }}$ World Rabbit Congress. Qingdao (China). World Rabbit Science Association (WRSA), pp. 293-296
Lounaouci-Ouyed G., Berchiche M., Gidenne T., 2011. Effects of incorporation of high levels (50-60\%) of hard wheat bran on mortality, digestibility, growth and body composition of rabbits of white population under Algerian conditions of production (in French). In: Proceedings of the 14èmes Journées de la Recherche Cunicole. Le Mans (France)

MADR (Ministry of Agriculture and Rural Development), 2016. Statistics (in French: Statistiques). Ministry of Agriculture and Rural Development (Ministère de L'agriculture et du Développement Rural) (Algeria)

Mennani A., Arbouche R., Arbouche Y., Montaigne E., Arbouche F. Arbouche H.S., 2017. Effects of incorporating agro-industrial by-products into the diet of New Zealand rabbits: Case of rebus of date and apricot kernel meal. Vet. World 10, 1456-1463, https://doi.org/10.14202/vetworld.2017.1456-1463

Mennani A., Arbouche Y., Arbouche R., Montaigne E., Arbouche F., Arbouche H.S., 2019. Effects of incorporating cull dates and apricot kernel cake on fattening performances and carcass characteristics of local rabbits J. Ponte 75(9), https://doi. org/10.21506/j.ponte.2019.9.4

Ouzzir L., Arbouche F., Arbouche Y., 2020. Byproducts in rabbit food: case of detoxified apricot kernel meal. J. Ponte 76(6), https:// doi.org/10.21506/j.ponte.2020.6.8

Ouhayoun J., Cheriet S., Lapanouse A., 1983 Comparative utilization of diets with different crude protein levels in rabbits selected on growth rate and in farm rabbits. 1. Growth performance and weight gain composition (in French). Ann. Zootech. 32, 257-246, https://doi.org/10.1051/animres:19830301

Peiretti P.G., Gai F., Rotolo L., Gasco L., 2012. Effects of diets with increasing levels of dried tomato pomace on the performances and apparent digestibility of growing rabbits. Asian J. Anim. Vet. Adv. 7, 521-527, https://doi.org/10.3923/ ajava.2012.521.527

Peiretti P.G., Gai F., Rotolo L., Brugiapaglia A., Gasco L., 2013. Effects of tomato pomace supplementation on carcass characteristics and meat quality of fattening rabbits. Meat Sci. 95, 345-351, https://doi.org/10.1016/j.meatsci.2013.04.011

Sawal R.K., Bhatia D.R., Bhasin V., 1996. Incorporation of tomato pomace in the diet of rabbits. Indian J. Anim. Nutr. 13, 35-38

Sayed A.B.N., Abdel-Azeem A., 2012. Evaluation of dried tomato seeds as feedstuff in the diets of growing rabbits. Int. J. Agro Vet. Med. Sci. 6, 263-268, https://doi.org/10.5455/ijavms.151

Sonelgaz, 2019. Sonelgaz - National Electricity and Gas Company. Algiers (Algeria), https://www.sonelgaz.dz

Valerie H., Tran G., 2016. Tomato pomace, tomato processing co-product (in French: Marc de tomate - Coproduit de transformation de la tomate). Association Francaise de Zootechnie (France), https://idele.fr/?elD=cmis download\&olD=workspace://SpacesStore/c708df7f-7ca94f85-ad36-d1d3d6bbdbb7

Wang J., Su Y., Elzo M.A., Jia X., Chen S., Lai S., 2016. Comparison of carcass and meat quality traits among three rabbit breeds. Korean J. Food Sci. Anim. Res. 36, 84-89, https://doi. org/10.5851/kosfa.2016.36.1.84 